\title{
The effectiveness of the zoning of China's protected areas
}

\author{
Weihua Xu ${ }^{\mathrm{a}, *}$, Xiaosong Li ${ }^{\mathrm{b}}$, Stuart L. Pimm ${ }^{\mathrm{c}}$, Vanessa Hull ${ }^{\mathrm{d}}$, Jingjing Zhang a ${ }^{\mathrm{a}}$ Lu Zhang a , Yi Xiao ${ }^{\mathrm{a}}$, \\ Hua Zheng ${ }^{\mathrm{a}}$, Zhiyun Ouyang ${ }^{\mathrm{a}}$ \\ a State Key Laboratory of Regional and Urban Ecology, Research Center for Eco-Environmental Sciences, Chinese Academy of Sciences, Beijing 100085, China \\ ${ }^{\mathrm{b}}$ Key Laboratory of Digital Earth Science, Institute of Remote Sensing and Digital Earth, Chinese Academy of Sciences, P. O. Box 9718, Beijing 100101, China \\ c Nicholas School of the Environment, Box 90328, Duke University, Durham, NC 27708, USA \\ ${ }^{\mathrm{d}}$ Center for Systems Integration and Sustainability, Department of Fisheries and Wildlife, Michigan State University, East Lansing, MI 48823, USA
}

\section{A R T I C L E I N F O}

\section{Article history:}

Received 10 July 2016

Received in revised form 4 October 2016

Accepted 20 October 2016

Available online 2 November 2016

\section{Keywords:}

Protected area

Conservation planning

Zoning

China

Nature reserves

\begin{abstract}
A B S T R A C T
Increasing human numbers and aspirations threaten protected areas worldwide. China faces especially strong pressure since many people live inside protected areas. It has sought to balance human needs and conservation goals within them by creating mixed zoning schemes loosely based on UNESCO's Man and the Biosphere Programme. These include strictly-protected core zones, buffer zones allowing limited human use, and experimental zones that examine different land-use options. To test the efficacy of this zoning, we employed field surveys and remote sensing to assess the penetration of agricultural and urban land into 109 national nature reserves in China for 2000 and 2010. Human disturbance was lowest in core zones and highest in experimental zones in both 2000 and 2010 . Over this period, $82 \%$ of the reserves were unchanged or had decreased human disturbance. Nonetheless, overall human disturbance increased by $7 \%, 4 \%$, and $5 \%$ in the core, buffer and experimental zones respectively. Almost all the increase in the core zone was in four wetland reserves, where human actions converted large areas to agriculture. Some $58 \%$ of reserves experienced some human disturbance in core zones in 2010 , demonstrating a need for more effective zoning. The findings have broader implications for protected area management globally because they highlight the strengths and weaknesses of zoning for balancing human needs and species conservation.
\end{abstract}

(c) 2016 Elsevier Ltd. All rights reserved.

\section{Introduction}

Protected areas are the principal means of stemming the current loss of biological diversity that now sees extinctions a thousand times faster than the background rate (Pimm et al., 2014). Terrestrial protected areas have more than quadrupled in extent since the 1970s (Watson et al., 2014). Currently, there are $>290,000$ of them worldwide, covering $15.4 \%$ of the total land area (Juffe-Bignoli et al., 2014) and 3.4\% of the total ocean area (Juffe-Bignoli et al., 2014). International biodiversity targets aspire to protect $17 \%$ of the land by 2020 (Tittensor et al., 2014). But do protected areas protect biodiversity? First, they are not always in the right places to do so (Rodrigues et al., 2004). For example, they cover from 4 to $25 \%$ of major biomes with those in cold or very dry (and so often remote) areas covering proportionately more habitat than areas suitable for human use (Jenkins and Joppa, 2009).

\footnotetext{
* Corresponding author at: State Key Laboratory of Regional and Urban Ecology, Research Center for Eco-Environmental Sciences, Chinese Academy of Sciences, Beijing 100085, China.

E-mail addresses: xuweihua@rcees.ac.cn (W.Xu), lixs@radi.ac.cn (X. Li), stuartpimm@me.com (S.L. Pimm), hullvane@gmail.com (V. Hull), 794419317@qq.com (J. Zhang), luzhang@rcees.ac.cn (L. Zhang), xiaoyi@rcees.ac.cn (Y. Xiao), zhenghua@rcees.ac.cn (H. Zheng), zyouyang@rcees.ac.cn (Z. Ouyang).
}

Second, human activities within protected areas vary greatly from near total exclusion to strong encouragement. IUCN places protected areas into various classes that reflect these different uses and human impacts (Dudley, 2008, Juffe-Bignoli et al., 2014). This paper's general objective is to ask: what model of protection works best, given that totally excluding people may be counterproductive?

In 1974, UNESCO's Man and the Biosphere Programme answered by proposing mixed zoning (UNESCO, 1974, Batisse, 1986, Ishwaran et al., 2008). There can be three zones (Liu and Li, 2008, Ma et al., 2009), variously given different names by different countries. One zone (often referred to as the "core" zone) is for conservation. It allows only a few human activities. The second zone is for human activities and regulated development. A third zone is a buffer zone to lie in between these two zones. It has some allowable human activities, thereby aspiring to soften the impact of human activities from the human activity zone on the core zone (Liu and Li, 2008). The potential benefit to these zoning designations is that they may provide a set of guidelines for spatial arrangements of multiple and sometimes competing uses across space. This model aspires to enhance biodiversity protection by acknowledging and accommodating the needs of local communities (Ma et al., 1998, Naughton-Treves et al., 2005, Ma et al., 2009, Coetzer et al., 2014). This paper examines the efficacy of this zoning. 
Many countries have adopted this zoning scheme, either as part of belonging to the Biosphere Programme or as a separate and independent regulation for protected area management (Batisse, 1997). Globally, zoning has had mixed effectiveness. Some report that it succeeds in allowing humans and nature to coexist without compromising the needs of the other (Kenchington and Day, 2011). Others point out challenges with successful zoning stemming from logistical constraints of demarcating boundaries between zones and enforcing zoning rules (Hull et al., 2011). Many questions remain. Most evaluations have been on designing zoning schemes to maximize coverage of conservation targets (Villa et al., 2002, Sabatini et al., 2007, Geneletti and van Duren, 2008). Fewer studies evaluate the functioning of zoning schemes after they are in place. Most studies on zoning efficacy are also single case studies that are difficult to place in broader context. There are few comprehensive analyses of zoning at larger regional scales to identify common factors influencing success or failure.

Here, we conduct an analysis of the efficacy of zoning designations in protected areas across China. China's protected areas face particular challenges. Despite their protected status, over 10 million people still live inside of them (Xu et al., 2016). To both manage conservation and human development goals, the Chinese government has stipulated that all officially designed national nature reserves be zoned according to the UNESCO guidelines. In the Chinese system, the three zones that are required for every nature reserve are referred to as the core zone (for biodiversity protection), the experimental zone (for human activities equivalent to UNESCO MAB's "transition zone"), and the buffer zone (to soften the boundary between the two). We adopt a spatially explicit approach to quantify amounts of human disturbance and trends in ecosystem changes in protected areas across these zones from 2000 to 2010.

As the world's most populous nation and one undergoing a rapid industrialization, China has faced severe environmental problems in recent years (Liu and Diamond, 2005). For instance, up to $90 \%$ of the nation's grasslands are degraded via a variety of threats including overgrazing, climate change, and mining. Soil erosion from deforestation has created massive flooding in the nation's major rivers that has produced billions of dollars in damages (Liu and Diamond, 2005). Other issues include species endangerment, invasive species, and poor water and air quality (Liu and Diamond, 2005). Establishment of protected areas has been one of the primary means the government has employed to combat these threats (Liu et al., 2003, Xu et al., 2009). One of the primary types of protected areas is nature reserves. By the end of 2014, China had created 2729 nature reserves, encompassing roughly $15 \%$ of its land area (Ministry of Environmental Protection of the People's Republic of China, 2015). By 2010, 319 were national nature reserves - the highest level of protection.

Several already-known issues with the implementation of zoning schemes in China and elsewhere include lack of clear regulations for how to structure the spatial arrangement of zones and lack of guidelines that dictate which factors should be considered (Liu and Li, 2008). There is also a lack of regulatory framework to manage zoning revisions that have commonly taken place to allow for future development in areas previously designated as the "core" (Hull et al., 2011). A few select studies evaluate the efficacy of zoning schemes in China's protected areas (Hull et al., 2011). These are isolated case studies of single reserves. They prevent drawing broad conclusions and identifying national trends. We quantify amounts of human disturbance and trends in ecosystem change in different zones in protected areas from 2000 to 2010. We also reflect on the role that zoning can play in broader conservation initiatives in China and elsewhere.

\section{Methods}

\subsection{Nature reserve selection}

We selected a subset of China's nature reserves from a dataset from the Nanjing Institute of Environmental Sciences of Ministry of
Environmental Protection (MEP) to include in the analysis. For selection, a nature reserve needed to satisfy four criteria. First, it must be in mainland China: Taiwan, Hong Kong, and Macao have different classification systems for protected areas. Second, it must be a national nature reserve - a formal designation. Information on zoning of regional nature reserves was not available. National nature reserves were well represented in each province and each type of major ecosystem including forest, grassland, wetland and desert. Third, it must be established and updated to a national level before 2000. Finally, it must have had no zoning boundary adjustments between 2000 and 2010. The selected 109 nature reserves were in 30 provinces of the 31 provinces- the exception was Tianjin - and they covered $5.9 \%$ of the land surface of China (Fig. 1). They accounted for $25-38 \%$ of the total numbers of national reserves numbers in seven regions of China (i.e. Northeast, North, Northwest, Southwest, South, East, and Middle) (Fig. 1).

\subsection{Evaluation of zoning effectiveness}

We obtained land cover data from the MEP and the Chinese Academy of Sciences. These data used an objected-oriented classification of Landsat TM and $\mathrm{HJ}$ imagery $(30 \mathrm{~m} \times 30 \mathrm{~m}$ resolution) based on extensive field surveys from $>100,000$ plots covering the entire country. Eight land cover types were classified in both years. The two of most interest were the agricultural land and urban land. These two types of land cover are available in most of land cover datasets and constitute our measures of human disturbance. We combined these as an indicator of human disturbance. Classification accuracy ranged from 76 to $97 \%$ across the 8 classes and was 95\% for both agricultural land and urban land (Ouyang et al., 2016). We compared the amounts of agricultural and urban land between 2000 and 2010 across core zones, buffer zones, and experimental zones. Paired-sample $t$-test was carried out in SPSS for detecting the differences between different zones.

\section{Results}

\subsection{Human disturbance across core, experimental and buffer zones}

In 2000, 108 of the 109 reserves had human disturbance inside them, with the average proportion of $1.7 \%$ of their total human disturbance area of $9932 \mathrm{~km}^{2}$ (Fig. 2 provides examples and Fig. 3 summarises the results.) There was more human disturbance in reserves in the east - where more of China's population live - than in the west. The average proportion was $0.4 \%$ in southwest and northwest regions, but was $15.4 \%$ in the remaining regions (e.g. northeast, north, east, south, and middle). Average amounts of urban land $(<1 \%)$ were lower than agricultural land (1-3\%) across the three zones. In 2000, the proportion of human disturbance in the core zone, $1.2 \%$, was significantly lower than buffer zones, $1.4 \%,(p<0.001)$ and it was significantly lower than experimental zones, $2.7 \%(p=0.001)$. These same differences were also significant in different management zones in 2010.

From 2000 to 2010, area of urban and agricultural land increased in each of the three management zones. This increase occurred at $18 \%$ of the core zones, $24 \%$ of the buffer zones, and $38 \%$ of the experimental zones. Urban land increased by $8.8 \%$ ( or $8.6 \mathrm{~km}^{2}$ ), $8.7 \%\left(12.8 \mathrm{~km}^{2}\right.$ ) and $11.0 \%$ ( or $40.0 \mathrm{~km}^{2}$ ) in the core, buffer and experimental zones respectively. Agricultural land increased by $6.7 \%$ (or $157.3 \mathrm{~km}^{2}$ ), $3.4 \%$ $\left(86.1 \mathrm{~km}^{2}\right)$ and $4.4 \%$ (or $195.0 \mathrm{~km}^{2}$ ) in the core, buffer and experimental zones respectively. Combined, the human disturbance areas increased by $6.8 \%, 3.7 \%$, and $4.9 \%$ in the core, buffer and experimental zones respectively.

\subsection{Human disturbance in core zones}

There was human disturbance in most of the core zones of the nature reserves we evaluated. In 2000, 64 (59\%) of reserves had human disturbance in core zones. Among them, $28 \%$ had human disturbance 


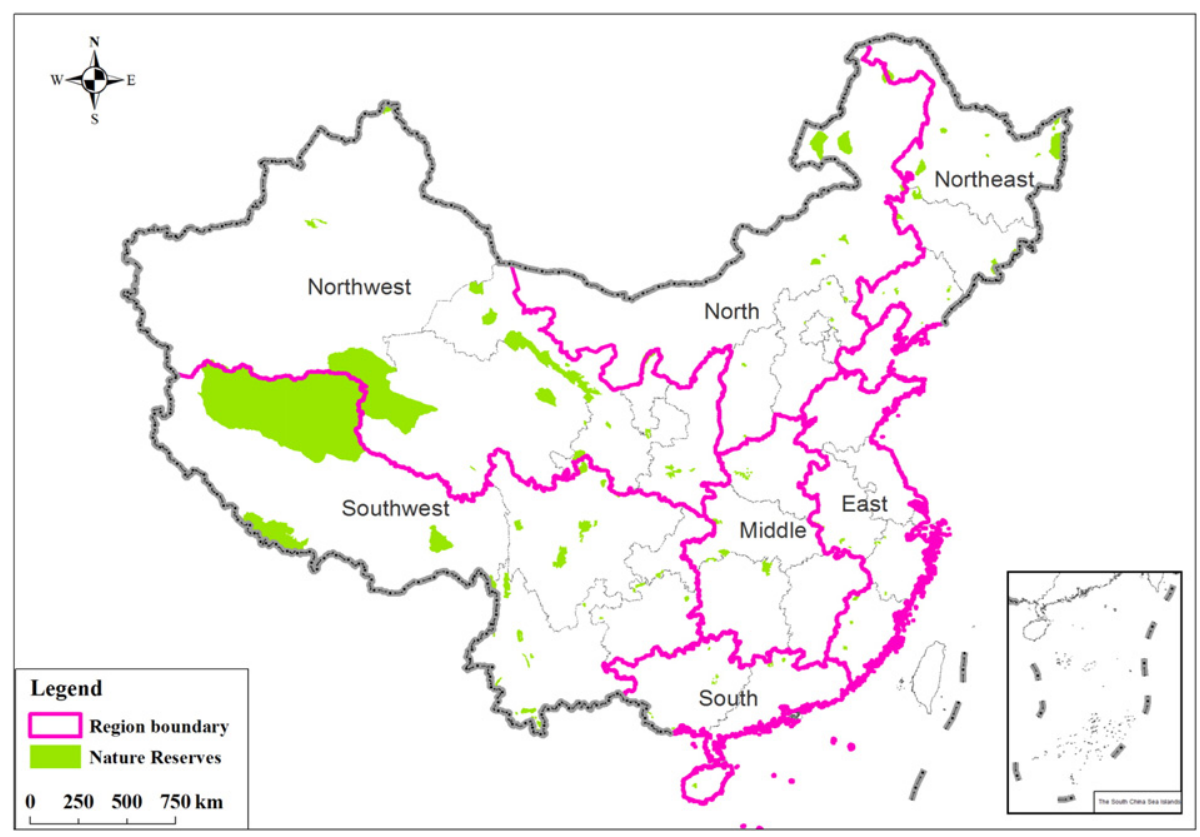

Fig. 1. Distribution of the nature reserves evaluated in China.

in $<1 \%$ of the total core zone area. However, $6 \%$ of reserves had $>20 \%$, including Xianghai, Sanjiang in northeast Plain. The average human disturbance area across all reserves was $23 \mathrm{~km}^{2}$, occupying $1 \%$ of the core zones, on average.

In 2000, the average proportions of agricultural land and urban land were $6.5 \%$ and $<1 \%$ for wetland reserves, followed by $4.2 \%$ and $<1 \%$ for forest reserves, and $<1 \%$ and close to zero for pasture and desert reserves. From 2000 to 2010, of the 109 reserves evaluated, 71 (65\%) of the reserves had no change in the area of human disturbance. For 18
(17\%) the extent of human disturbance decreased. In total, $31 \mathrm{~km}^{2}$ decreased in human disturbance (this excludes the conversion between urban and agricultural land). Of this, 91\% was agricultural land that became wetland and forest.

Twenty (18\%) of the reserves experienced increases in human disturbance in the core zone. In total, human disturbance expanded by a $166 \mathrm{~km}^{2}$ area between 2000 and 2010. Of this, 93\% involved wetland and pasture converted to agricultural land. Some $94 \%$ of the increased human disturbance was from just four reserves.

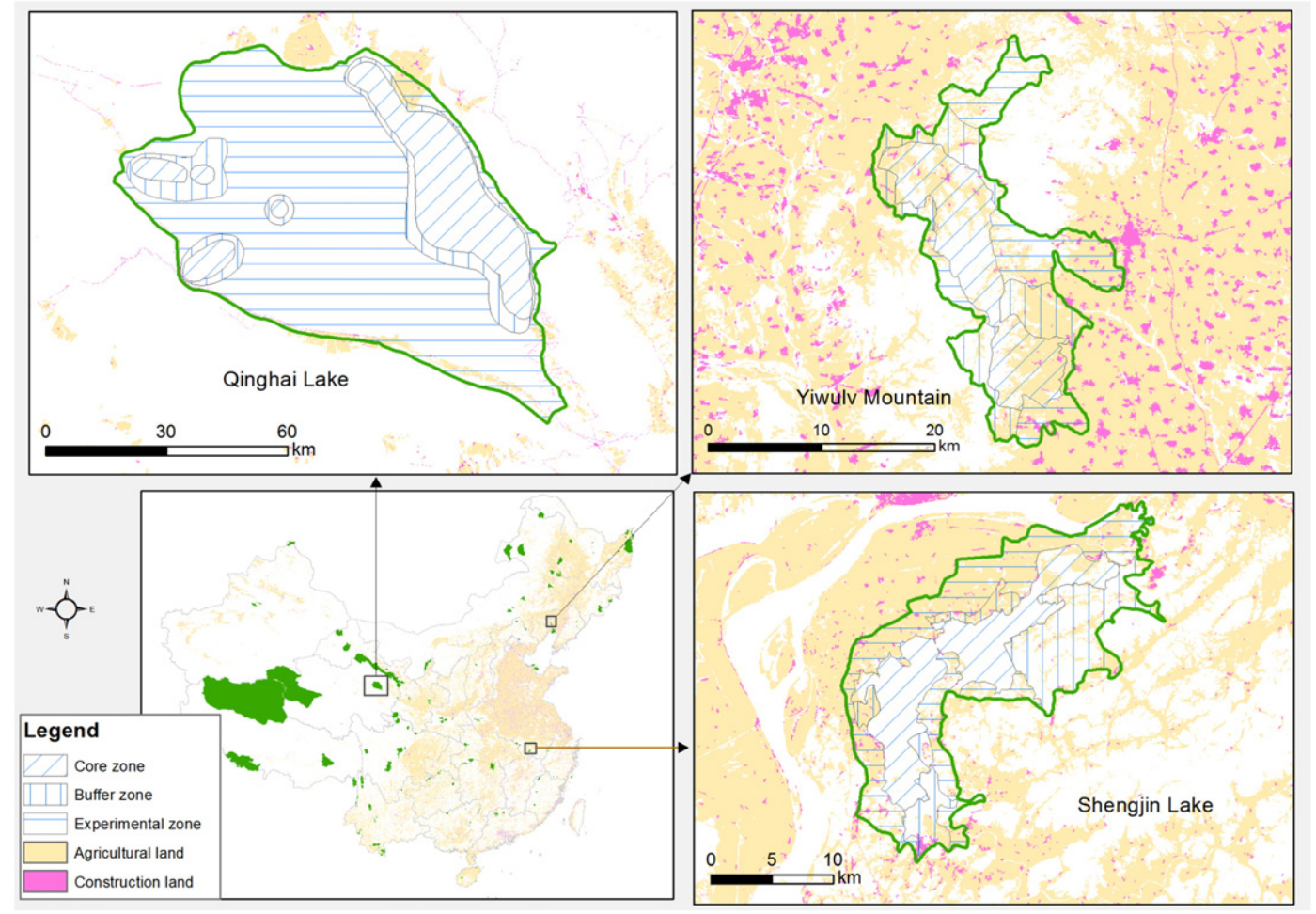

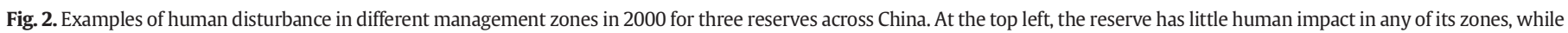
the other two examples had agricultural land and some human construction even in the core zones when the reserves were established. 

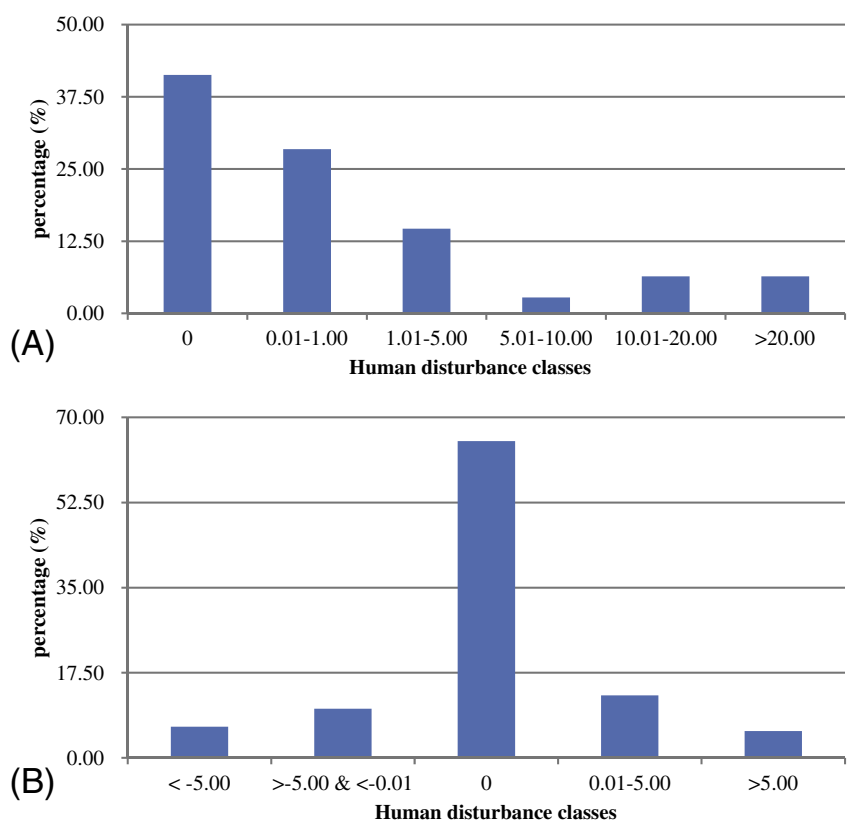

Fig. 3. Percentage of human disturbance land in core zones in China's nature reserves, (A) Percentage in 2000, and (B) percentage change between 2000 and 2010.

As the results of urban land and agricultural land change, $58 \%$ of the reserves had human disturbance in core zones in 2010 . Of them, $41 \%$ of reserves had urban land, and $47 \%$ had agricultural land. In addition, 30\% had both urban land and agricultural land.

\section{Discussion}

We evaluated the efficacy of zoning designations in protected areas across China measuring two major types of human disturbance: agricultural land and urban land. Our results show some positive impacts of zoning. There was less human disturbance inside core zones than in buffer and experimental zones. Moreover, $82 \%$ of the reserves had unchanged or decreased human disturbance in core zones from 2000 to 2010 , which is higher than in buffer zones (76\%) and experimental zones (62\%). The efficacy of zoning designations still could be improved, however: there was still some human disturbance inside the core zones of $58 \%$ of the reserves we evaluated, with urban land in $41 \%$ of core zones.

Moreover, overall the total area of human disturbance increased by $7 \%$ in core zones from 2000 to 2010 , almost all of it the massive conversion of a few wetlands. There are several underlying reasons. First, forest was clearly defined and did not change to any great extent. In contrast, wetland can be changed easily and defined as pasture or land that suffers from salinization. China has implemented a natural forest policy with strict protection, but pasture can be used. Lands suffering from salinization can be converted to urban or agricultural land since they were classified as unused land in the national land-use classification system before 2007 (Song and Pijanowski, 2014). Even when famers convert wetlands to agricultural land, they will receive less punishment than if they $\log$ forests. Second, climate change and water resource competition can cause wetlands to be converted to pasture or salinized lands that can then easily be converted to agricultural land. Third, since 2004 the policy of direct agricultural subsidy on crops and subsequent cancelling taxes on crops since 2006 encouraged local farmers to expand the areas of crop land to get more income (Zhang et al., 2008). Finally, many wetland nature reserves do not have land tenure. This is one of major reasons for wetland loss inside them.

Adjustment of the zoning of nature reserves also diminished its effectiveness. Between 2000 and 2010, 17 out of 319 national reserves adjusted their zones. There might be several reasons for this. One reason is that there might have been too much human disturbance in reserves during their establishment. For instance, $>100,000$ people live inside the Baishuijiang National Nature Reserve. It was established in 1970s and is a famous biosphere reserve for the conservation of giant panda. Some villages were even inside the core zones, making management difficult. Areas with high human density were subsequently adjusted to be outside the reserve. In addition, some boundary adjustment was due to the change of protection targets. The Anhui Yangtze crocodile reserve was established in 1970s. Due to shrinking habitat of over 30 years, the reserve was adjusted. Other adjustments were due to national construction projects. For instance, the core zone of Taihangshan National Nature Reserve was adjusted to become an experimental zone due to the construction of the Jijing Highway (Qin et al., 2005). Although some adjustment was due to the construction, this adjustment of a national reserve was nonetheless difficult due to the strict procedures in effect. Adjustments due to national construction projects still need to be approved by a committee of national nature reserves and agreed by the State Council. Thus, even when there was some adjustment occurred in reserves, the zoning may still be generally effective.

Another important factor is zoning design and nature reserve management. First, a good zoning design needs a scientific set of guidelines informed by field surveys about local species, ecosystems and human distribution. Such supporting data were missing for most nature reserves. Thus, agricultural land and human residential areas were included inside the core zones at the outset for many nature reserves (Huyan et al., 2014).

Second, the connectivity between core zones inside or between reserves was not properly considered during the planning stage. Sometimes, there were several isolated core zones within one reserve. There was also no regional planning. Nature reserves located in the same region were established in different years, and nature reserves established later did not consider the compatibility with the other reserves established earlier. This resulted in the isolation of core zones. For instance, core zones in the connected panda reserves in Qinling Mountain Range are in 20 separate, isolated areas (Xu et al., 2010).

Third, zoning was only "on paper" for some reserves and many reserve administrations did not implement the plans. There were no obvious signs on the ground showing the boundaries between different management zones (Liu and Li, 2008, Hull et al., 2011). There were no measures for controlling the people entering the buffer and core zones.

Other policies on zoning were important. On one side, conservation polices that restore natural habitats such as the Grain to Green Program (GTGP) and Natural Forest Conservation Program (NFCP), both instituted in late the 1990s and early 2000s at the national level (Liu et al., 2008), have contributed greatly to the stability or reduction of human disturbance in $82 \%$ of the core zones from 2000 to 2010 . Conversely, the development policies promoted by national and local governments throughout China in recent years have increased human disturbance in many nature reserves. Mining, tourism, hydropower stations, and associated urban such as roads and hotels contributed greatly to the income for local governments. Due to strict limitations against development in core zones, local governments have promoted the adjustment of boundaries of reserves or management zones to avoid punishment. This is despite the original purpose of the boundary adjustment policy being mainly to better protect endangered species and their ecosystems if their distribution changed. During the period of 2000 to 2010, human disturbance occurred in core zones without or before approval for boundary adjustment by the central government.

\section{Recommendations}

To improve management, we recommend three measures. The first is to lessen the pressure of human activates on nature reserves at a large scale. Conservation policies such as NFCP and GTGP, and other policies issued recently such as compensation for people living in areas of key ecological function or priority areas for biodiversity, should be 
continued in counties with reserves. Furthermore, the government should use the national-level new urbanisation plan (2014-2020) as an opportunity to lessen human pressure on reserves. The plan calls for 100 million people to be relocated from rural to urban areas (the State Council of the People's Republic of China, 2014). As of yet, they do not stipulate specific goals with regard to reserves. The government should also take various measures related to improving education and reducing energy consumption to promote population migration from nature reserves, especially in areas where they have large impacts on core zones and buffer zones. Previous trends in China have shown that educated people are more likely to move out of protected areas to new jobs in cities. In addition, new infrastructure such as roads and railways should avoid passing through nature reserves. These measures might greatly promote the effectiveness of zoning in nature reserves.

Second, the management of nature reserves needs to be strengthened according to the management requirement of different zones. First, guidelines on zoning should be specified to meet the conservation requirements of different types of ecosystems and species. For instance, zone boundaries for freshwater reserves might be changed according to the seasonal change of water level. But they are fixed for forest reserves. Second, zoning work should be carried out to all levels of nature reserves due to the lack of zoning for many local reserves. The boundaries of different zones should be clearly labelled on the ground. Third, species and ecosystem monitoring is essential in the reserves at a regional level. So, too, is coordination of zoning among neighbouring reserves. It is also necessary to monitor human disturbance in nature reserves especially in core and buffer zones using field surveys and high-resolution satellite images at reasonable intervals.

Third, it would be worthwhile to consider changing the performance evaluation systems for local governments. Currently, the central government evaluates local governments mainly according to their economic performance and with less consideration for natural resources and ecological protection. Recently a new performance evaluation method - ecological capital evaluation - has been proposed for local governments that would allow counties with more ecological resources to focus more on ecological protection and restoration, instead of purely economy development (China Daily, 2015). This evaluation system could benefit protected areas because many local governments use funds allocated from the central government to directly or indirectly support protected areas in their counties.

Improvement of the effectiveness of zoning in protected areas will contribute to China's goals of slowing or reversing declining trends in natural ecosystems throughout the nation. As one of the major approaches for balancing development and environmental protection, zoning will benefit the effectiveness of protected areas systems as a whole. In addition, zoning should ideally be combined with other conservation tools and also be revised over time to respond to emerging issues such as new human impacts, climate change, or natural disasters (Hannah et al., 2007, Hull et al., 2011).

\section{Global implications}

We asked: what model of protection works best, given that totally excluding people may be counterproductive? To what extent do our results answer this question and what generalities might we deduce from them? For China, across its huge area and exceptionally diverse ecosystems, most core areas withstood land conversion to crops or to cities. In some areas, agricultural land regenerated forest. Where there was human disturbance, it was typically there are the start, a consequence of where the authorities established the boundaries of protected areas. Buffer and experimental zones suffered substantial land conversion, which begs the question of whether their designation as such makes any difference. So, to a first approximation, protected areas protect, while ambivalent "multiple-use" strategies do not clearly do so. As with other experiences, it is the exceptions that may be the most interesting. Four wetland areas suffered massive conversion of core areas.
The conclusion is that protected area status alone is insufficient when there are incentives to destroy natural areas and insufficient enforcement to prevent that.

The general question of whether protected areas with adjacent multiple use zones far better than comparable areas without is not answered by this study. It is a particularly difficult question to answer, of course, given it suggests that one would need comparisons of areas with and without the three zoning strategies. The very extensive conversions of multiple use areas adjacent to zones raises the issue of whether they have any benefit to the biodiversity in the core area.

\section{Acknowledgments}

This work was supported by Ministry of Science and Technology through the National Key Programme of Research and Development Project (2016YFC0503200), and the Ministry of Finance of China through the MEP/CAS project "Survey and Assessment of National Ecosystem Changes Between 2000 and 2010, China" (No. STSN-04-00). We thank Dr. Chen Xiaodong for constructive suggestions to the paper. We acknowledge Nanjing Institute of Environmental Sciences for providing national nature reserves data.

\section{References}

Batisse, M., 1986. Developing and focusing the biosphere reserve concept. Perspectives in Resource Management in Developing Countries. 1, pp. 160-177.

Batisse, M., 1997. Biosphere reserves: a challenge for biodiversity conservation \& regional development. Environment: Science and Policy for Sustainable Development 39, 6-33.

China Daily, 2015. Auditing Outgoing Officials' Management of Natural Resource Assets. Available at: http://www.chinadaily.com.cn/opinion/2015-09/24/content_ 21965856.htm.

China, the State Council of the People's Republic of China, 2014. Plan of National New Urbanization (2014-2020).

Coetzer, K.L., Witkowski, E.T.F., Erasmus, B.F.N., 2014. Reviewing biosphere reserves globally: effective conservation action or bureaucratic label? Biol. Rev. 89, 82-104.

Dudley, N., 2008. Guidelines for Applying Protected Area Management Categories. IUCN, Gland, Switzerland.

Geneletti, D., van Duren, I., 2008. Protected area zoning for conservation and use: a combination of spatial multicriteria and multiobjective evaluation. Landsc. Urban Plan. 85, 97-110.

Hannah, L., Midgley, G., Andelman, S., Araújo, M., Hughes, G., Martinez-Meyer, E., Pearson, R., Williams, P., 2007. Protected area needs in a changing climate. Front. Ecol. Environ. $5,131-138$

Hull, V., Xu, W., Liu, W., Zhou, S., Vina, A., Zhang, J., Tuanmu, M., Huang, J., Linderman, M., Chen, X., Huang, Y., Ouyang, Z., Zhang, H., Liu, J., 2011. Evaluating the efficacy of zoning designations for protected area management. Biol. Conserv. 144, 3028-3037.

Huyan, J., Xiao, J., Yu, B., Xu, W., 2014. Research progress in function zoning of nature reserves in China. Acta Ecol. Sin. 34, 6391-6393.

Ishwaran, N., Persic, A., Tri, N.H., 2008. Concept and practice: the case of UNESCO biosphere reserves. International Journal of Environment and Sustainable Development 7, 118-131.

Jenkins, C.N., Joppa, L., 2009. Expansion of the global terrestrial protected area system. Biol. Conserv. 142, 2166-2174.

Juffe-Bignoli, D., Burgess, N.D., Bingham, H., Belle, E.M.S., de Lima, M.G., Deguignet, M., Bertzky, B., Milam, A.N., Martinez-Lopez, J., Lewis, E., Eassom, A., Wicander, S., Geldmann, J., van Soesbergen, A., Arnell, A.P., O'Connor, B., Park, S., Shi, Y.N., Danks, F.S., MacSharry, B., Kingston, N., 2014. Protected Planet Report 2014 UNEP-WCMC. UK, Cambridge Available at. http://wdpa.s3.amazonaws.com/WPC2014/protected_ planet_report.pdf.

Kenchington, R., Day, J., 2011. Zoning, a fundamental cornerstone of effective Marine Spatial Planning: lessons learnt from the Great Barrier Reef, Australia. J. Coast. Conserv. $15,271-278$.

Liu, J., Diamond, J., 2005. China's environment in a globalizing world. Nature 435, $1179-1186$

Liu, X., Li, J., 2008. Scientific solutions for the functional zoning of nature reserves in China. Ecol. Model. 215, 237-246.

Liu, J., Ouyang, Z., Pimm, S.L., Raven, P.H., Wang, X., Miao, H., Han, N., 2003. Protecting China's biodiversity. Science 300, 1240-1241.

Liu, J., Li, S., Ouyang, Z., Tam, C., Chen, X., 2008. Ecological and socioeconomic effects of China's policies for ecosystem services. Proc Natl. Acad Sci. 105, 9477-9482.

Ma, Z., Li, W., Wang, Z., Tang, H., 1998. Habitat change and protection of the red-crowned crane (Grus japonensis) in Yancheng Biosphere Reserve, China. Ambio. 27, 461-464.

Ma, Z., Li, B., Li, W., Han, N., Chen, J., Watkinson, A.R., 2009. Conflicts between biodiversity conservation and development in a biosphere reserve. J. Appl. Ecol. 46, 527-535.

Ministry of Environmental Protection of the People's Republic of China, 2015l. China Environmental Condition Bulletin. :p. 2014 Available at. http://www.zhb.gov.cn/gkml/ hbb/qt/201506/t20150604_302942.htm. 
Naughton-Treves, L., Holland, M.B., Brandon, K., 2005. The role of protected areas in conserving biodiversity and sustaining local livelihoods. Annu. Rev. Environ. Resour. 11, 219-252.

Ouyang, Z., Zheng, H., Xiao, Y., Polasky, S., Liu, J., Xu, W., Wang, Q., Zhang, L., Xiao, Y., Rao, E., Jiang, L., Lu, F., Wang, X., Yang, G., Gong, S., Wu, B., Zeng, Y., Yang, W., Daily, G.C., 2016. Improvements in ecosystem services from investments in natural capital. Science 352, 1455-1459.

Pimm, S., Jenkins, C., Abell, R., Brooks, T., Gittleman, J., Joppa, L., Raven, P., Roberts, C. Sexton, J., 2014. The biodiversity of species and their rates of extinction, distribution, and protection. Science 344, 1246752.

Qin, W., Jiang, M., Wang, Z., Liu, L., 2005. Function zone readjustment and its ecological impact on Henan Taihangshan Macaca mulatta Chinensis National Nature Reserve. Rural Eco-Environment 21, 78-80.

Rodrigues, A.S.L., Andelman, S.J., Bakarr, M.I., Boitani, L., Brooks, T.M., Cowling, R.M., Fishpool, L.D.C., da Fonseca, G.A.B., Gaston, K.J., Hoffmann, M., 2004. Effectiveness of the global protected area network in representing species diversity. Nature 428 , 640-643.

Sabatini, M.d.C., Verdiell, A., Iglesias, R.M.R., Vidal, M., 2007. A quantitative method for zoning of protected areas and its spatial ecological implications. J. Environ. Manag. 83, 198-206.

Song, W., Pijanowski, B.C., 2014. The effects of China's cultivated land balance program on potential land productivity at a national scale. Appl. Geogr. 46, 158-170.

Tittensor, D.P., Walpole, M., Hill, S.L.L., Boyce, D.G., Britten, G.L., Burgess, N.D., Butchart, S.H.M., Leadley, P.W., Regan, E.C., Alkemade, R., Baumung, R., Bellard, C., Bouwman, L., Bowles-Newark, N.J., Chenery, A.M., Cheung, W.W.L., Christensen, V., Cooper, H.D., Crowther, A.R., Dixon, M.J.R., Galli, A., Gaveau, V., Gregory, R.D., Gutierrez, N.L.,
Hirsch, T.L., Höft, R., Januchowski-Hartley, S.R., Karmann, M., Krug, C.B., Leverington, F.J., Loh, J., Lojenga, R.K., Malsch, K., Marques, A., Morgan, D.H.W., Mumby, P.J., Newbold, T., Noonan-Mooney, K., Pagad, S.N., Parks, B.C., Pereira, H.M., Robertson, T., Rondinini, C., Santini, L., Scharlemann, J.P.W., Schindler, S., Sumaila, U.R., Teh, L.S.L., van Kolck, J., Visconti, P., Ye, Y., 2014. A mid-term analysis of progress toward international biodiversity targets. Science 346, 241-244.

UNESCO, 1974. Task Force on Criteria and Guidelines for the Choice and Establishment of Biosphere Reserves. Paris, 20-24 May 1974. MAB Report No. 22. UNESCO Paris, France.

Villa, F., Tunesi, L., Agardy, T., 2002. Zoning marine protected areas through spatial multiple-criteria analysis: the case of the Asinara Island National Marine Reserve of Italy. Conserv. Biol. 16, 515-526.

Watson, J.E., Dudley, N., Segan, D.B., Hockings, M., 2014. The performance and potential of protected areas. Nature $515,67-73$.

Xu, H., Tang, X., Liu, J., Ding, H., Wu, J., Zhang, M., Yang, Q., Cai, L., Zhao, H., Liu, Y. 2009. China's progress toward the significant reduction of the rate of biodiversity loss. Bioscience $59,843-852$.

Xu, W., Luo, C., Ouyang, Z., Zhang, L., 2010. Designing regional nature reserves group: the case study of Qinling Mountain Range, China. Acta Ecol. Sin. 30, 1648-1654.

Xu, W., Gao, J., Xia, X., Zhou, D., Li, Z., Jiang, M., 2016. Distribution of community residents in nature reserves and its impacts on the reserves in China. Journal of Ecology and Rural Environment 32, 19-23.

Zhang, C., Tong, L., Liu, J., 2008. Evaluation of coordinated development of arable land and wetlands in Sanjiang Reserve. Sci. Geogr. Sin. 28, 343-347. 